\title{
Computer-Assisted Design of Sheet Metal Component Formed from Stainless Steel
}

\section{Računalniško Podprto Načrtovanje Preoblikovanja Pločevinnske Komponente iz Nerjavne Pločevine}

\author{
Tomaž Pepelnjak,*, Tomaž Bren², Bojan Železnik², Mitja Kuštra' \\ ${ }^{1}$ Fakulteta za strojništvo Ljubljana, Aškerčeva 6, 1000 Ljubljana, Slovenia \\ ${ }^{2}$ KGL d.o.o., Proizvodnja in obdelava kovinskih izdelkov, Ponoviška cesta 13, 1270 Litija, Slovenija \\ * tomaz.pepelnjak@fs.uni-lj.si
}

\begin{abstract}
The development of the product from stainless steel, which is produced for the client in large series, is presented. Technological optimisation was mainly focussed on the design of the deep drawing process in a single operation, which proved to be technologically unstable and therefore unfeasible for the prescribed shape of the product. Testing of prototype products showed unacceptable wrinkling due to the coneshaped geometry of the workpiece. For this purpose, the research work was oriented towards technological optimisation of forming operations and set-up of proper phase plan in order to eliminate the wrinkling of the material. Testing of several different materials of the same quality was performed to determine the appropriate input parameters used for digital analyses. The analyses were focussed towards the set-up of optimal forming process and appropriate geometry of the corresponding tool, which allowed deep drawing of the workpiece without tearing and/or wrinkling of the material. Performed analyses of the forming process in the digital environment were tested with experiments, which showed a good correlation between the results of both development concepts.
\end{abstract}

Key words: deep drawing, conical part, stainless steel

\section{Povzetek}

Predstavljen je razvoj izdelka iz nerjavnega jekla, ki se za naročnika izdeluje $v$ masovni proizvodnji. Tehnološka optimizacija je bila fokusirana predvsem na načrtovanje procesa globokega vleka v eni operaciji, ki se je izkazala za tehnološko nestabilno in zaradi tega neizvedljivo za zahtevano obliko izdelka. Testiranje prototipne serije je pokazalo nedopustno gubanje materiala zaradi konične oblike preoblikovanca. Zaradi tega so raziskave bile usmerjene $\mathrm{v}$ tehnološko optimizacijo preoblikovalnih operacij in vzpostavitev ustreznega metodnega plana za odpravo gubanja materiala. Testiranje številnih materialov enake kakovosti so služili izbiri ustreznih vhodnih parametrov digitalnih analiz. Te smo fokusirali predvsem v vzpostavitev optimalnega preoblikovalnega procesa in izbire ustrezne geometrije pripadajočega orodja. Ta omogoča globoki vlek preoblikovanca brez gubanja in/ali trganja materiala. Izvedene analize preoblikovalnega procesa $\mathrm{v}$ digitalnem okolju so bile preverjene z eksperimenti, ki so pokazali dobro ujemanje rezultatov obeh razvojnih konceptov.

Ključne besede: globoki vlek, konični izdelek, nerjavna pločevina 


\section{Introduction}

In the automotive industry, immense use of steel and aluminium sheet metal components is a daily practice. The products are made either from multiple components, which are delivered as an assembly, or a single component, formed and/or machined to the desired shape tolerances and surface quality. Examples of deep drawn and punched products are shown in Figure 1.

Such a product was designed and developed as part of the presented project. The product was made from stainless steel in mass-production series. The customer determined the required demands for the shape of the product, as well as the required surface roughness of the active surfaces, which had to be polished after the process of drawing and stamping of the side holes was done (Figure 2). Owing to the cost-efficient nature of forming technology, the part was planned to be produced by a single-step forming process. However, first, technological trials and forming tests with the prototype tool showed that the conical shape of the product results in high unsupported region of the drawn part with critical tangential stresses, leading to the critical deformation and wrinkling of the conical part during the drawing process [1] (Figure 3). Additionally, the danger of material tearing due to insufficient clearance of the tool and blank holder force during the drawing process was experimentally confirmed.

The most evident error at the developed drawn part was the formation of wrinkles on the conical wall of the product, which is unacceptable for functional and aesthetic reasons and may cause also the die damage. The wrinkling of the formed parts has become a serious problem in recent years with the increased use of thin high strength sheet metals in the automotive industry [2]. The wrinkling phenomenon is directly related to the geometry of the workpiece, stress-strain state, material parameters, and anisotropy and contact conditions [3]. It occurs once the circumferential compressive stress is higher than the critical circumferential compressive stress of the sheet during forming [1]. The magnitude of the compressive stress is usually smaller than that causing the flange wrinkling. Owing to the unsupported region of the analysed part's wall [4], in comparison
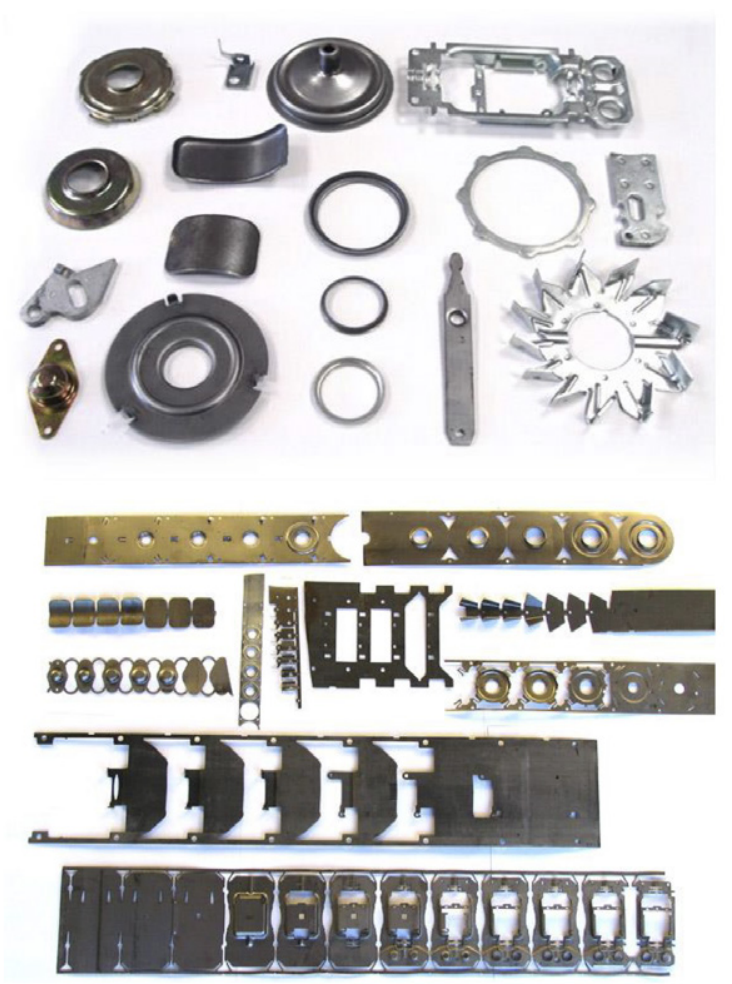

Figure 1: Referenced stamped and deep drawn parts [6].

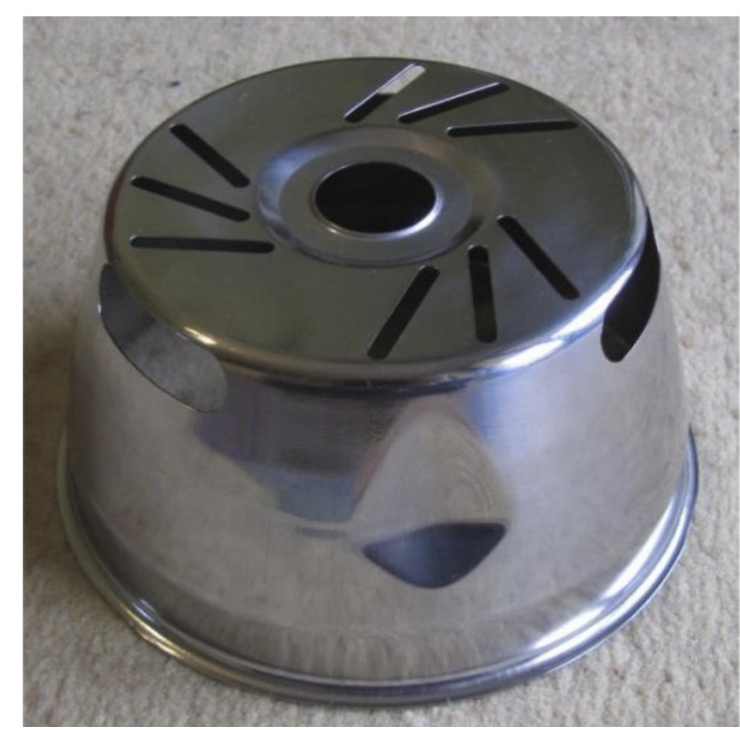

Figure 2: Finished product [7].

to the flange, it is more difficult to suppress the wrinkling in this area. However, the usage of stainless steel had beneficial implications, because it has a low value of anisotropy and a high value of hardening rate that consequently means that it has a better resistance to the formation of wrinkles [5]. 


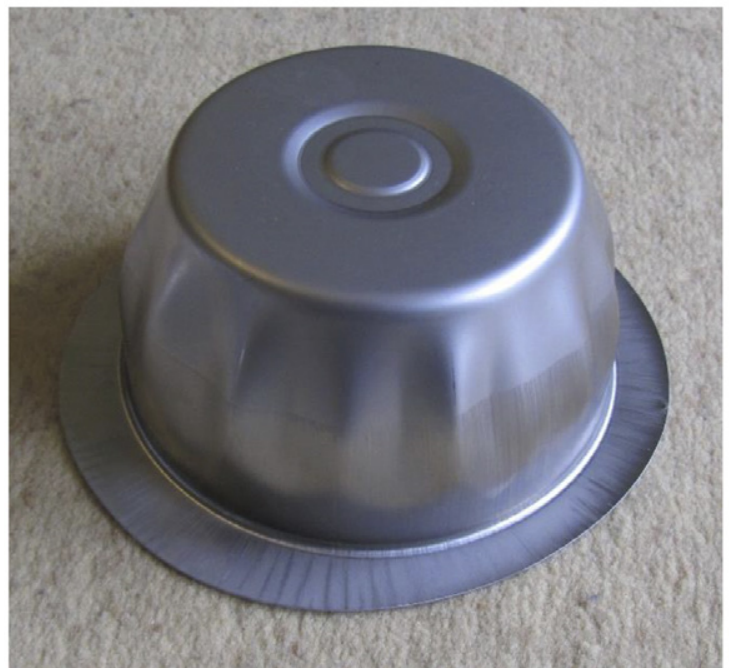

Figure 3: Wrinkling on the conical part of the drawn product.

The resolving of these critical mistakes and the optimisation of the production process were the main focuses of the present research, where the classic planning of the forming technologies and the modern computer-aided technologies with numerical simulations were used together. The optimisation of the forming process involved determining the following parameters:

- the optimal number of forming steps and the intermediate shape of the drawn workpiece after each step;

- the optimal tool clearance and the size of the drawing radii;

- the required blank holder force for the drawing to omit flange;

- minimal drawing steps to form part without cone wrinkling and

- the required calibration force for the shape stabilisation of the cone and embossed detail on the bottom of the product.

The last phase of the technological optimisation was conducted using the hydraulic press in the Forming Laboratory of the Faculty of Mechanical Engineering, University of Ljubljana. In this research phase following the numerical simulations, the fine-tuning of the technological parameters was determined. The experimental work in the last phase of the development also verified the numerical prediction of blank holder force and part calibration. The use of four different steels of the same quality obtained from four different manufacturers also verified the stability of the selected process.

\section{Materials}

The material that was chosen for the product was the most widely used stainless steel of 1.4301 quality, which can be easily acquired throughout Europe. This meant that the cost of material supply could be more easily optimised and the mass production could run without delays or interruptions. For quality, numerical analyses of the material and forming properties of the sheet metal had to be evaluated first. The flow curves of two analysed materials of same 1.4301 qualities are shown in Figure 4. Both materials exhibit very similar flow curves. The Ludwik approximation was used for curve fitting.

$\sigma_{f}=A+K \varphi_{e}^{n}$

Table 1 contains the information about the anisotropy, which plays an important role in the shaping of the product during the deep drawing process. Furthermore, it also shows the intensity of the material's thinning along the critical cross-section - the higher the anisotropy, the less intensive the localisation. The mean values of anisotropy are calculated according to the equation

$\bar{r}=\frac{1}{4}\left(r_{0}+2 \cdot r_{45}+r_{90}\right)$

whereas the planar anisotropy is calculated according to the equation

$\Delta r=\frac{1}{2}\left(r_{0}-2 r_{45}+r_{90}\right)$

As it can be seen from Table 1 and Figure 4, both materials exhibit very similar formability properties; therefore, only one value of the plasticity curve and the mean anisotropy value of the material were used to conduct numerical simulations. Because the values for anisotropy rely on the direction of the rolling, we can expect uneven properties of the workpiece along its perimeter and a noncircular flange, which has to be cut-off after the deep drawing process. 


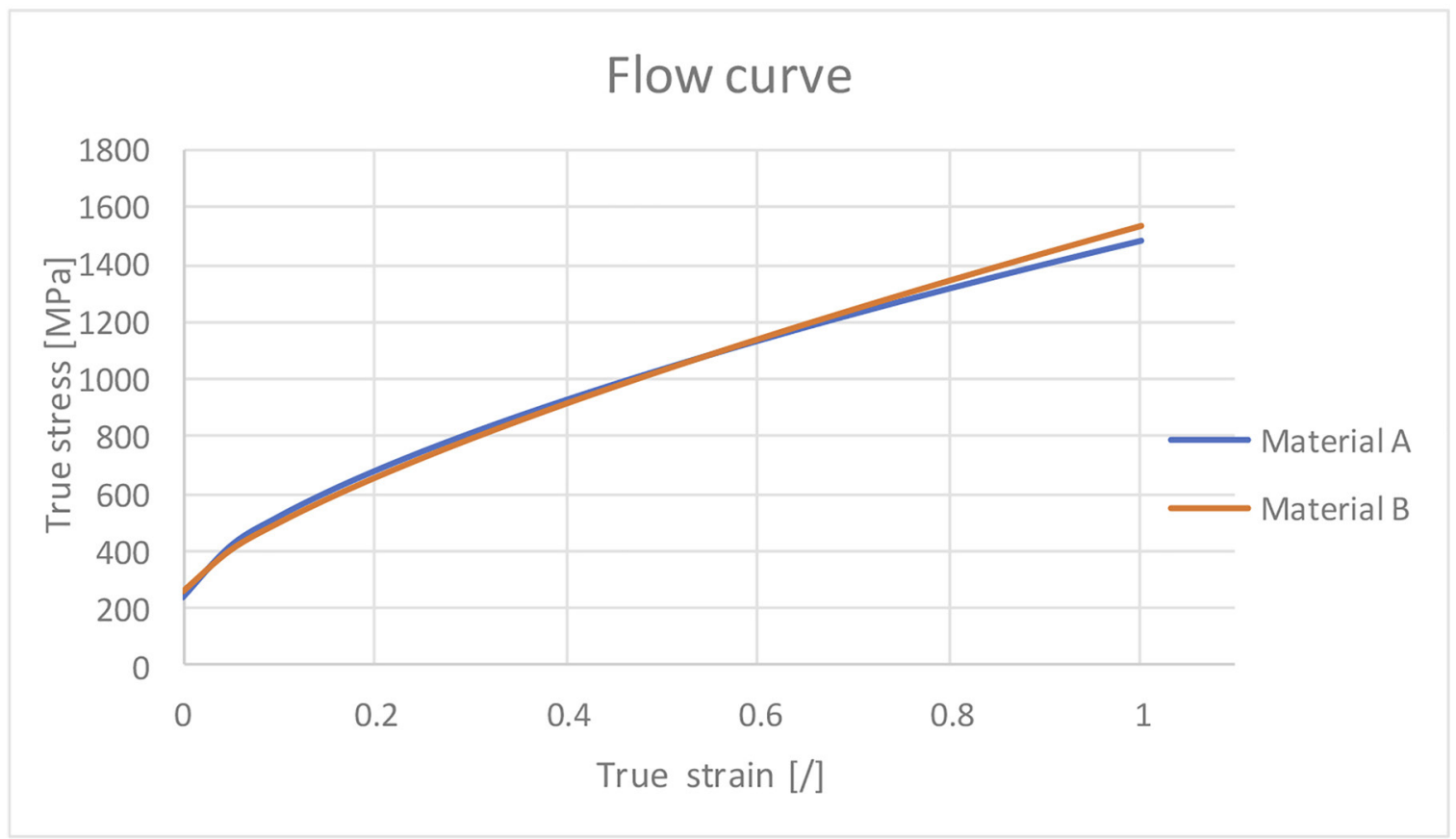

Figure 4: Flow curves of the analysed materials.

Table 1: Anisotropy of the material.

\begin{tabular}{ccc} 
Specimen position according to the rolling direction & Material A & Material B \\
\hline $0^{\circ}$ & 0.88 & 0.81 \\
\hline $45^{\circ}$ & 1.15 & 1.14 \\
\hline $90^{\circ}$ & 0.77 & 0.78 \\
\hline Average value of the anisotropy & 0.99 & 0.97 \\
\hline Planar anisotropy & -0.65 & -0.69 \\
\hline
\end{tabular}

\section{Finite element model}

The objects of the finite element model (FEM) used for the numerical simulation are shown in Figure 5. The FEM model consists of the blank, punch, counter-punch, die and blank holder. The blank was modelled as elastic-plastic, whereas all tool parts were considered as rigid objects. Considering the elastic behaviour of the blank, the Poisson ration of $v=0.3$ and Young's modulus of $E=210 \mathrm{GPa}$ were taken into account. The plastic behaviour followed the flow curve shown in Figure 4, considering also the anisotropic material properties from Table 1. The interaction conditions among all objects in contact followed the Coulomb's law
Table 2: Nodes and elements of FEM mesh.

\begin{tabular}{ccc} 
Model & Nodes & Elements \\
\hline Blank & 8073 & 7959 \\
\hline Punch & 5053 & 4999 \\
\hline Counter-punch & 773 & 716 \\
\hline Die & 882 & 820 \\
\hline Blank holder & 372 & 330 \\
\hline
\end{tabular}

with a coefficient of $\mu=0.1$. Table 2 presents the element size for each meshed object of the finite element simulation. 


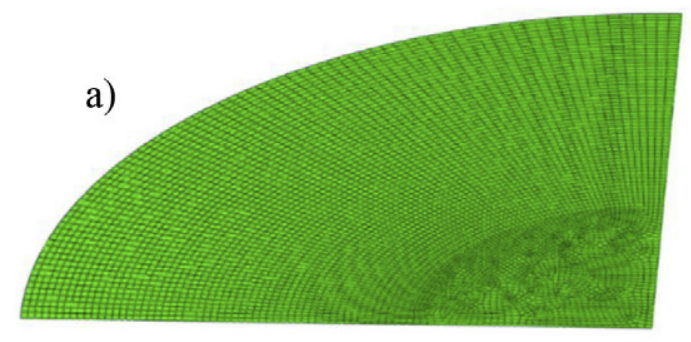

b)
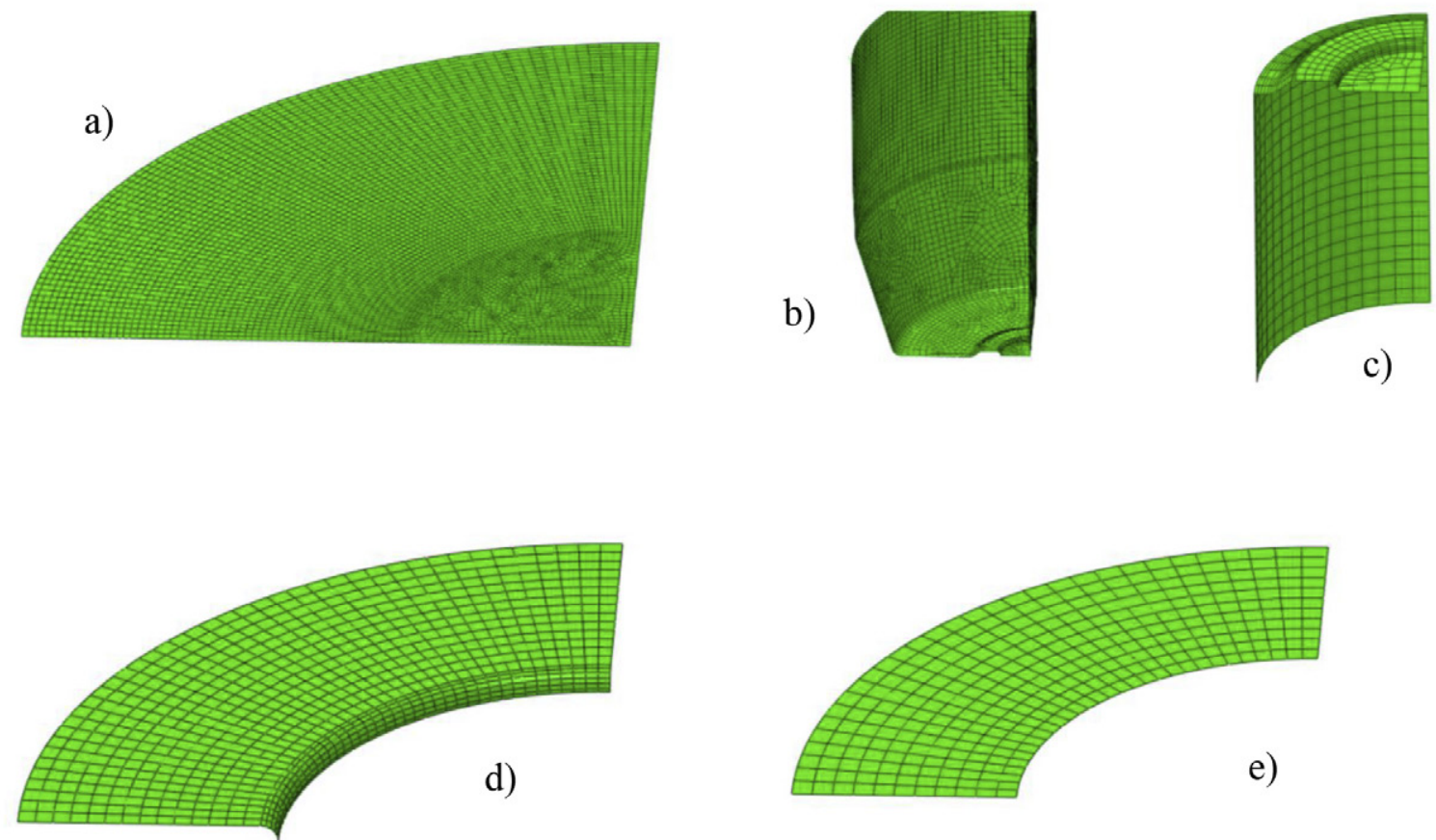

Figure 5: The FEM used for the numerical simulation: a) blank, b) punch, c) counter-punch, d) die and e) blank holder.

\section{Results}

In order to verify the prediction of the wrinkling occurring in the material during the single-step deep drawing process, the first phase of the development was to check the numerical model. Owing to the axis symmetry of the model, the analysis was done only with one-fourth of the whole workpiece. Through this, the computing time of the numerical analysis was reduced. The unfavourable drawing conditions in the single-step process of the numerical model have also expressed significant wrinkling of the cone-shaped part of the specimen (Figure 6). Some simulations also predicted the intensive thinning of the material at the narrower part of the cone, when certain tool optimisations were implemented (Figure 7). The analysis also focussed on determining a favourable radius of transition between the vertical part and the conical part of the product as well as the calibration of the conical shape of the product. The results show that calibration may reduce wrinkling but cannot eliminate it completely.

The wrinkling analyses on the vertical part and the conical part of the product were carried out using four different models. However, the anal- yses of the single-step deep drawing process have shown that all four different drawn parts have still measurable wrinkling on the coneshaped areas of the workpiece, which is shown in Figure 8. It is evident from Figure 8 that none of the optimised geometries could entirely eliminate the wrinkling phenomenon.

The analysis of different forming phase plans has shown that the basic shape of the product cannot be made by a single-step drawing process. Therefore, the technological process was divided into two forming steps. In the first deep drawing phase, the sheet metal was moved into a hat-shaped preform with a straight wall and a large radius on the bottom of the product (Figure 9, top and middle). In the second drawing phase, using the inverted drawing process with a movable die, the workpiece was drawn onto a fixed punch. Doing so, we increased the vertical height and created the conical half of the product (Figure 9, bottom). Using this two-phase approach, the analysis showed that the wrinkling has significantly decreased. The analysed nodes showed a fluctuation of the measured radius below the value of $0.5 \mathrm{~mm}$ along the circumference of the product. Because this fluctuation was still not admissible, the product had to be calibrat- 


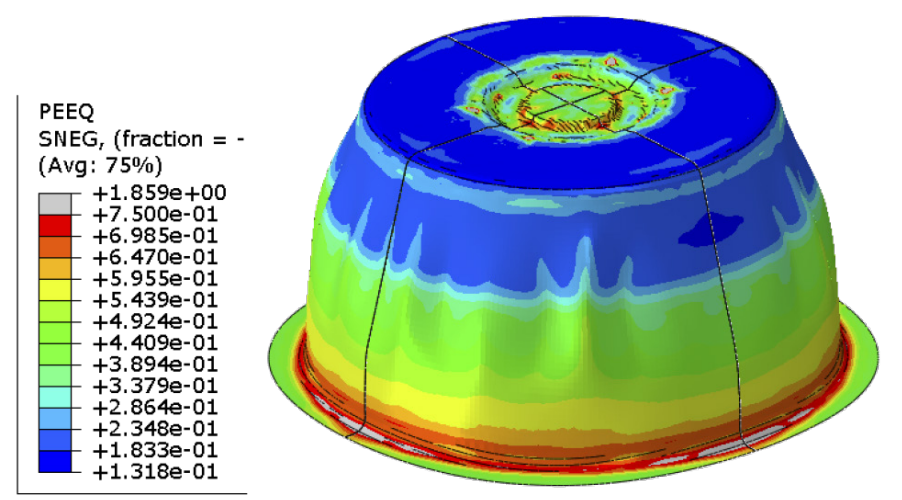

Figure 6: Analysis of wrinkling - equivalent strain.
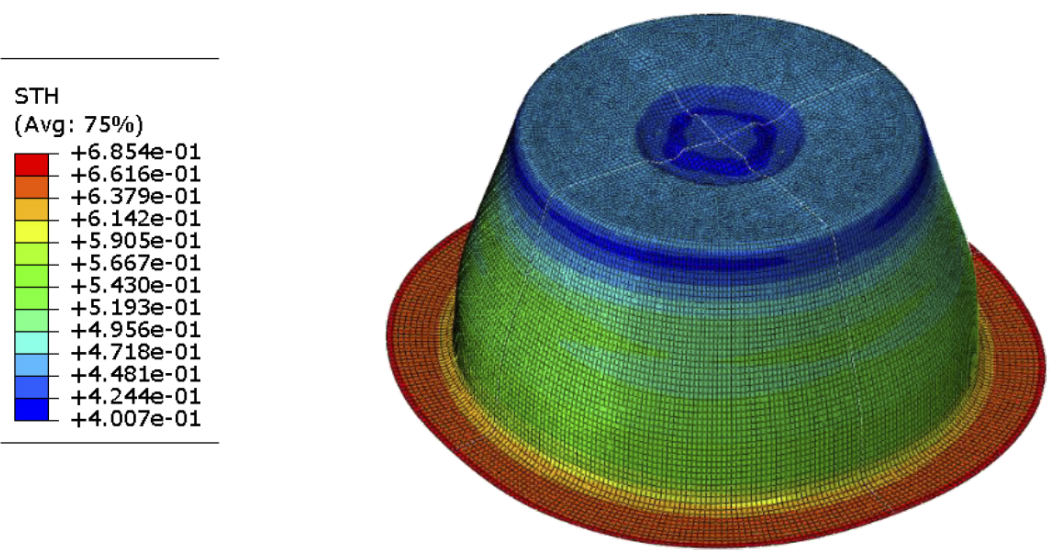

Figure 7: Analysis of material tearing - sheet thickness $(\mathrm{mm})$ of the drawn part.

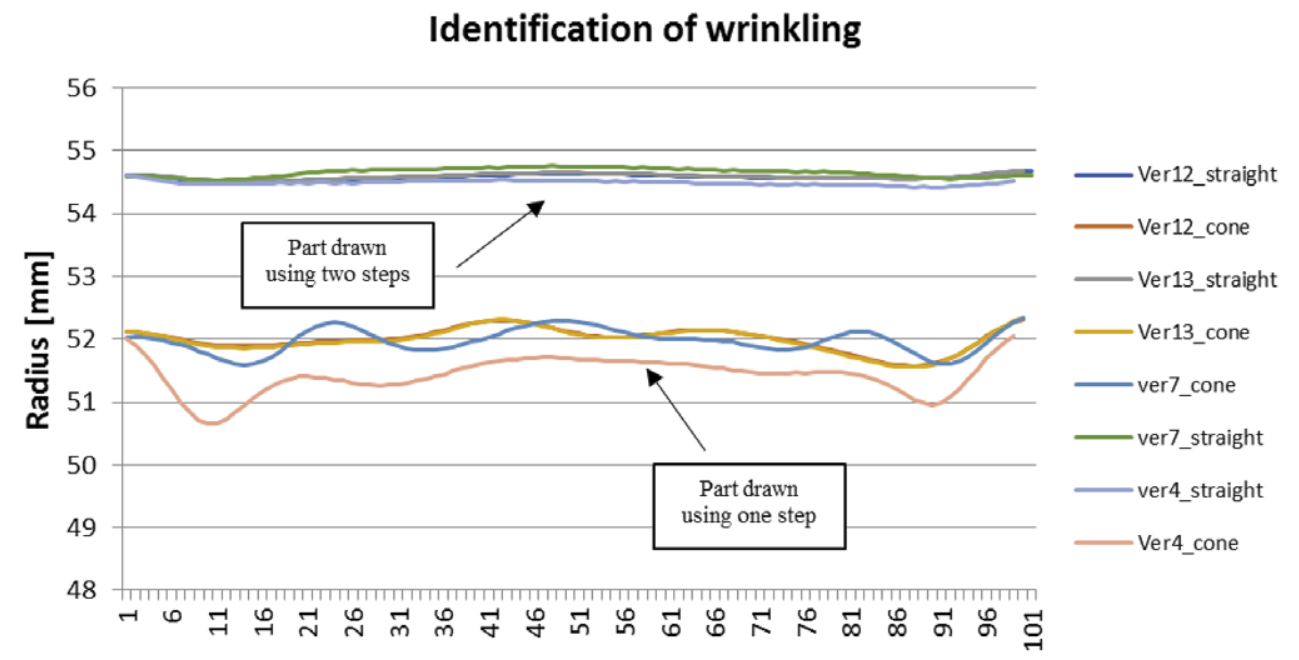

Successive measurement along the perimeter [mm]

Figure 8: Analysis of wrinkling along the part's perimeter. 


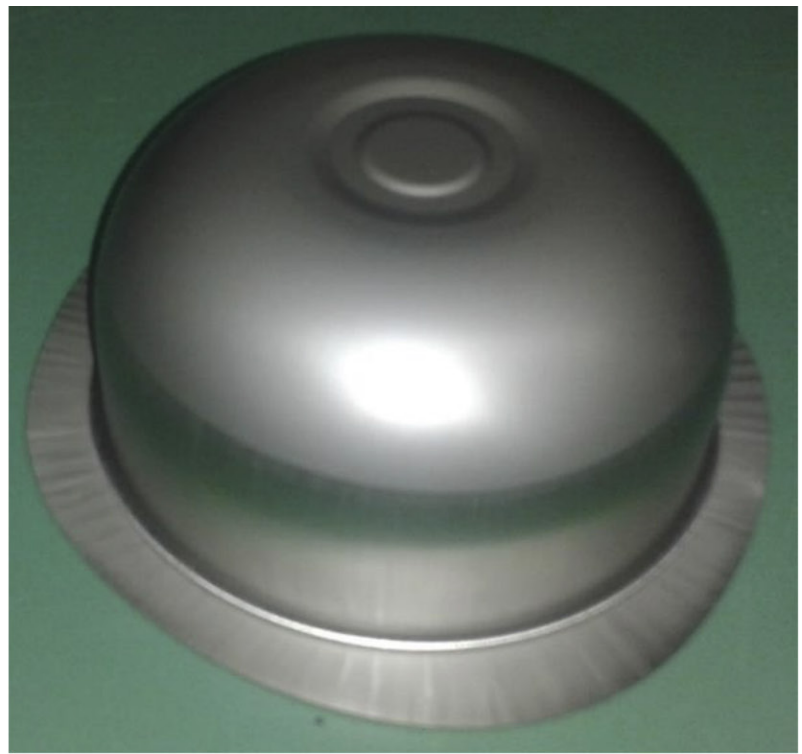

PEEQ

SNEG, (fraction $=-1.0$ )

(Avg: 75\%)
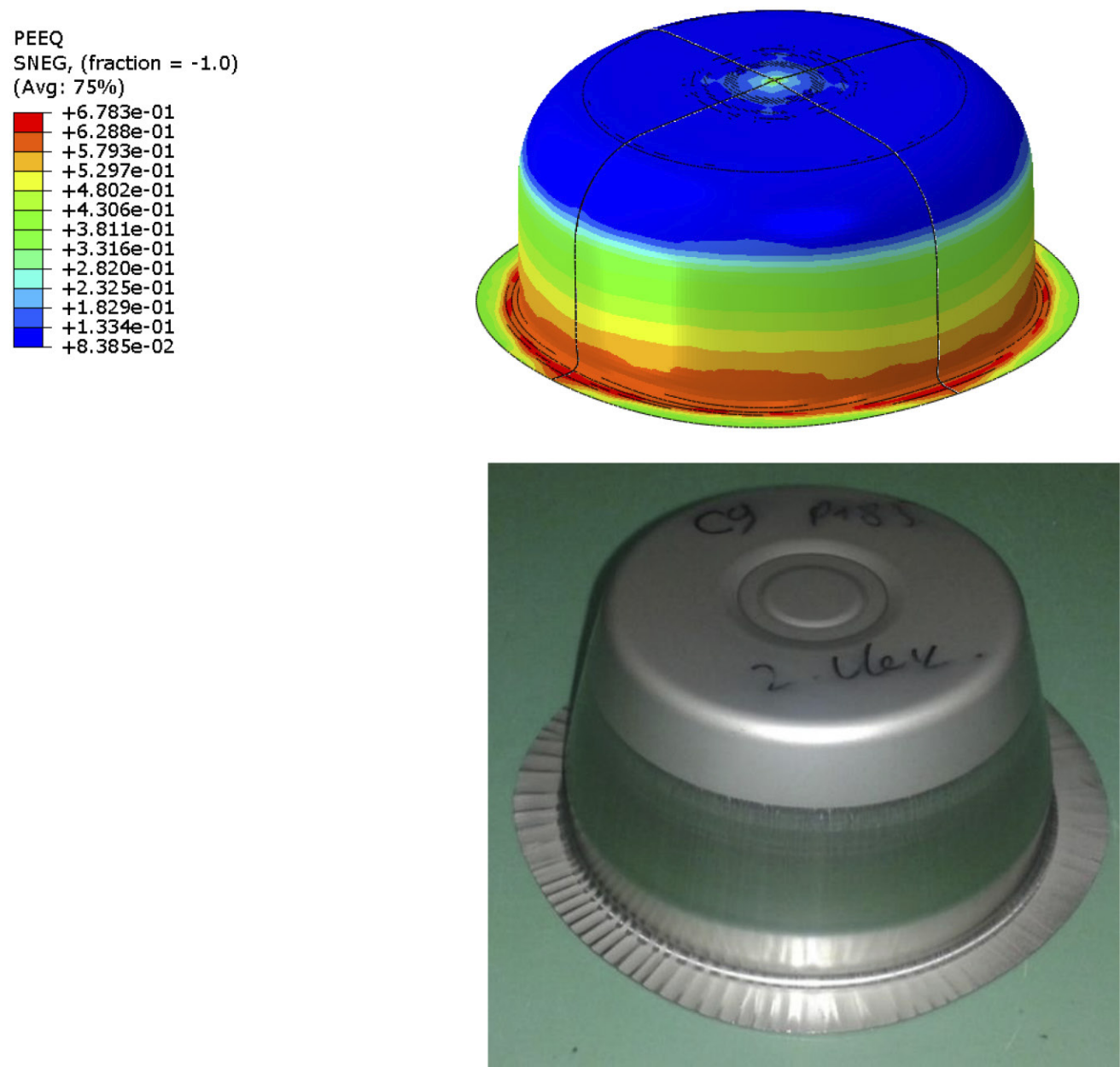

Figure 9: Chosen technology of the drawing: first drawing (top) and analysis of the comparison deformation of the first drawing (middle) and the second drawing with calibration (bottom). 


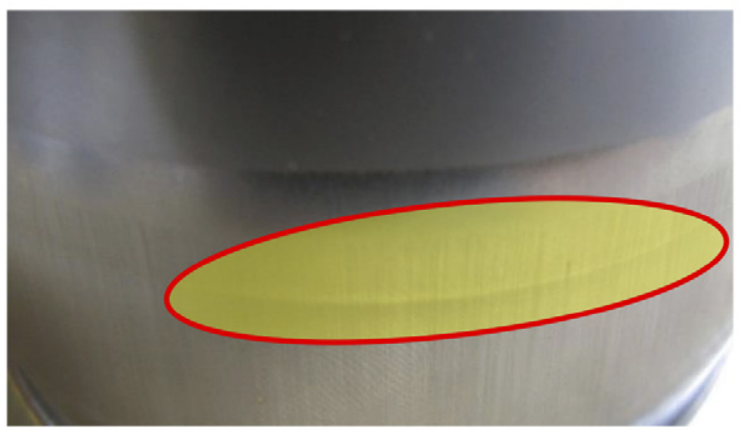

Figure 10: Detail of the calibrated part area at the end of the punch stroke.

ed at the middle of the conical part (Figure 10). Doing so, the wrinkling was entirely eliminated. The proper selection of the technological solution was verified using the test tool of the Faculty of Mechanical Engineering of Ljubljana. The fluctuations in the material property and different surface qualities (surface roughness) that arise due to different manufacturers of the 1.4301 steel were also assessed.

\section{Conclusions}

Design of the forming process of a conical workpiece made of stainless sheet metal showed the relevance of simultaneously conquering its production technology from the industrial partner supported by academic knowledge and analyses in the digital environment. The layout of the deep drawing process showed that due to the conical shape and successive wrinkling of the product, it is not feasible to perform the forming operation in one step only. For this reason, the two-step deep drawing process was selected, and the final conical shape was obtained in the second drawing phase with implemented calibration at the end of the punch stroke.

The deep drawing phases were followed by the operations of successive forming of the strengthening ribs, cutting, trimming and polishing of the final product. The product is already successfully integrated into the mass production without any tearing or wrinkling problems.

\section{Acknowledgement}

The authors acknowledge the support of the Slovenian Research Agency within the framework of programme P2-0248.

\section{References}

[1] Shafaat, M.A., Abbasi, M., Ketabchi, M. (2011): Investigation into wall wrinkling in deep drawing process of conical cups. Journal of Materials Processing Technology, 211(11), pp. 1783-1795, doi:10.1016/j.jmatprotec.2011.05.026.

[2] Neto, D.M., Oliveira, M.C., Santos, A.D., Alves, J.L., Menezes, L.F. (2017): Influence of boundary conditions on the prediction of springback and wrinkling in sheet metal forming. International Journal of Mechanical Sciences, 122, pp. 244-254.

[3] Nan, L., He, Y., Heng, L., Siliang Y. (2016): Plastic wrinkling prediction in thin-walled part forming process: A review. Chinese Journal of Astronautics, 29(1), pp. 1-14.

[4] Wang, X., Cao J. (2000): On the prediction of sidewall wrinkling in sheet metal forming processes. International Journal of Mechanical Sciences, 42, pp. 2369-2394.

[5] Naryanswamy, R., Sowerby, R. (1995): Wrinkling behaviour of Cold rolled sheet metals when drawing through a tractrix die. Journal of materials technology, 49, pp. 199-211.

[6] Železnik T.: KGL d.o.o., Available on: <http://www.kgl. si/stancanje.php - view 5.1.2018>.

[7] Železnik T.: KGL d.o.o., internal company material, Litija, 2017. 